\title{
Risks Of Sharia Commercial Bank In Indonesia: Analysis Of Internal And External Factors
}

\author{
Erlinda Kurnia Aufa', Cita Sary Dja'akum² \\ 1,2Universitas Islam Negeri Walisongo Semarang, Indonesia \\ lindaaufa39@gmail.com
}

\begin{abstract}
Purpose - This study aims to analyze the effect of inflation, gross domestic product (GDP), capital adequacy ratio (CAR), and financing to deposit ratio (FDR) to non performing financing (NPF) at Islamic Commercial Banks in Indonesia.

Method - The research approach used is a quantitative approach. Determination of samples is done by purposive sampling method. The data used is secondary data, obtained from publication reports on the official website of each Sharia Commercial Bank, Bank Indonesia, and the Central Statistics Agency. The population in this study were all Islamic Commercial Banks registered in the Statistics of Islamic Banking in Indonesia for the period 2013-2017. Based on the specified criteria, five Sharia Commercial Banks were obtained as research samples. This study uses panel data regression analysis with the Fixed Effects Model approach which is processed through the Eviews 10 program.
\end{abstract}

Result - The results of hypothesis testing show that partially Inflation has a positive but not significant effect on NPF, GDP has a significant negative effect on NPF, CAR has a negative but not significant effect on NPF, and FDR has a significant negative effect on NPF. Simultaneously inflation, GDP, CAR, and FDR have a significant effect on NPF.

Implication - This study uses all data from commercial Islamic bank.

Originality - This study analyzes the determining factors that influence financing risks from both internal and external factors.

Keywords: Non Performing Financing; Inflation, Gross Domestic Product; Capital Adequacy Ratio; Financing to Deposit Ratio. 
Erlinda Kurnia Aufa, Cita Sary Dja'akum

\section{Introduction}

Financing is one of the functions of the Bank that is the provision of facilities for providing funds to fulfill the needs of the parties who are experiencing a shortage of funds (deficit unit). However, in operating the AL-ARBAH | 82 financing function, the bank also has a risk that is financing risk, which is where the customer is unable to fulfill its obligations. This can be influenced by many factors. The more customers who are not able to keep their obligations (failed to pay), then the level of losses borne by the bank will get higher (Amin, et al., 2017).

Provision of financing based on sharia principles according to Law No. 10 of 1998 Article 8 is carried out based on analysis by establishing the precautionary principle so that customers are willing to pay off debts or return financing by the agreement so that the risk of failure or congestion and repayment can be avoided. Nevertheless, the financing provided to customers will not be free from the occurrence of problem financing which can ultimately affect the performance of the Islamic bank. Therefore, in its implementation Islamic banks always apply the precautionary principle (Machmud and Rukmana, 2010).

The amount of financing provided by Islamic Commercial Banks (ICB) and Sharia Business Units (SBU) has increased every year. In 2013, the amount of funding was Rp. 184.1 trillion, then in 2014 it dropped to Rp. 148.4 trillion, in 2015 it increased to Rp. 154.5 trillion, increased again in 2016 to Rp. 178 trillion. In 2017, financing went up to $6.47 \%$ from the position of Rp 178 trillion to Rp. 190.5 trillion.

The amount of financing that increases every year, in fact, it can not be separated from the risk of problematic financing which also has increased.In Islamic banking, the proxy is used to measuring the level of problem financing is the ratio of non-performing financing (NPF).The higher the NPF ratio, the higher the risk of financing to be borne by the bank. Due to the highly NPF bank should provide greater reserves, thereby reducing the capital reserves held by banks (Amin, et al., 2017). 
The current financing increased from year to year. Non-current financing also increased approximately 10\% each year, both non-current financing which is substandard, doubtful and loss. The non-current financing category which has the highest number every year is bad financing. The increase in non-performing or non-performing financing (NPF) was experienced by banks caused banks to lose their ability to generate optimal profits from these main activities. the increasing problem financing gets the positive impact generated by financing disbursement cannot occur. This is because operating income from financing is very small because the profit-sharing margins that should be received by banks from the distribution of financing are not received in full.

The cause of this problematic financing can be caused by internal and external sides. Internal influence is an influence that comes from operational activities within the banking itself as outlined in financial performance. Financial performance of a bank can be seen through its financial ratio as an indicator of health as well as an analysis tool for predicting profits will be generated. Meanwhile, external influences are macroeconomic factors (Auliani and Syaichu, 2016). In this study, the authors analyze the factors that affect NPF on Islamic Commercial Banks based on internal and external factors.

Based on the background above, this study aims to determine how the influence between inflation, gross domestic product, capital adequacy ratio, and financing to deposit ratio partially and simultaneously on nonperforming financing at Islamic Commercial Banks in Indonesia.

\section{Literature Review}

The main function of a bank is to provide loans to customers. Loans are the most significant source of bank income. However, banks as business entities are also not free from various risks. The main risk in the banking business is a credit risk. In Sharia banking literature, the term credit risk is better known as financing risk. Heffernan (2005) defines credit risk is the risk that occurs because customers cannot return loans to banks due to default. 
More broadly, at least the risk of financing contains three components (Indonesian Bankers Association, 2015). 1). Opportunity to default (probability of default), namely the inability of the debtor to meet its obligations to the bank; 2). Exposure financing (exposure financing), which is related to the potential amount of loss if the debtor defaults; 3 ). Recovery rate (recovery rate), which is the rate of return on financing that has failed to pay as an effort to restore bank performance.

The study of financing risks in Islamic banks has attracted many parties. Research on the factors that drive financing risk in Islamic banks is very important for related parties such as bank management and regulators. Many previous studies have measured the risk of financing using a non-performing financing (NPF) ratio. In the banking world, financing is in the NPF category when loan payments have exceeded 90 days or more. The higher NPF will cause bank profit margins to decrease. Even if it gets bigger it can cause a crisis in the bank itself.

The majority of research on financing risk is taken up by two factors such as internal and external factors. Internal factors are the variables that are in the bank (bank-specific variables) such as capital, profitability, financing growth, total assets, management quality and so on. Meanwhile, external factors are macroeconomic variables, for instance; economic growth, inflation, exchange rates, policy rates and others (Misman, et al., 2015). Previous research on financing risk can only consist of bank-specific variables as well as macroeconomic variables. Some other studies combine these two variables like bank-specific variables and macroeconomic variables.

Specific variables of banks in previous research include capital adequacy using Capital Adequacy Ratio (CAR). CAR is a ratio of the amount of capital both core capital and supplementary capital to risk-weighted assets (RWA). Capital adequacy is a very important factor for banks to deal with the risk of loss, especially the risk of loss for non-repayment of financing provided to their customers. Asnaini (2014) explains that when CAR at Islamic Commercial Banks increases, then Syariah Commercial Banks will feel safe to channel their financing. However, this results in Sharia Commercial Banks 
feeling loose in terms of financing distribution. If this condition occurs, the risk of financing is given to improper customers will be even greater, so that if it is not collectible, it will increase the NPF.

Another specific bank variable is the financing to deposit ratio (FDR). The FDR variable is the level of ability of an Islamic bank in channeling third-party funds were collected by the Islamic bank concerned. The maximum FDR allowed by $\mathrm{BI}$ is $110 \%$. The higher the distribution of funds channeled through financing, the possibility of risk financing problems will increase, so that the NPF will also increase (Asnaini, 2014). The results of a studyconducted by Popita (2013) stated that FDR had no significant positive effect on NPF. The results of these studies differ from studies conducted by Setiawan and Putri (2013) showing that FDR has a significant positive effect on NPF. This statement was supported by Haifa and Dedi (2015) which in his research also stated that FDR had a significant positive effect on NPF.

External factors causing problematic financing from macroeconomic variables can be seen from the level of inflation. Martiningsih (2014) states that the increase in the inflation rate will also be followed by an increase in problem financing for banks. The results of the study were supported by research by Linda et al. (2015). However, Mutamimah and Chasanah (2012) in their research concluded that inflation has a negative effect on the NPF ratio.

Another problem that affects the NPF of macroeconomic variables is gross domestic product (GDP). Gross domestic product is used to measure all goods and services produced by a country in a certain period. It shows that GDP is an indicator of economic growth which is an important measure in explaining economic performance which is directly the performance of economic actors providing goods and services including the banking industry (Purnamasari and Musdholifah, 2016). Firmansari and Suprayogi (2015) state that GDP has a significant and positive influence on NPF. The results of this study are supported by research by Shingjergi and Iva Shingjergi (2013). However, Mutamimah and Chasanah (2012) say that GDP has no significant effect on NPF. 
Erlinda Kurnia Aufa, Cita Sary Dja'akum

\section{Methods}

The dependent variable in this study is the NPF variable as a proxy of financing risk. Meanwhile, the independent variables in this study consisted of bank-specific variables and macroeconomic variables. The research variables of the bank-specific factors used are CAR and FDR while the GDP and inflation variables are used as a proxy of macroeconomic factors. The data used are secondary data, obtained from publication reports on the official websites of each Sharia Commercial Bank, Bank Indonesia, and the Central Statistics Agency. The research period is 2013-2017 and in the form of quarterly data. Sharia Commercial Bank data used as research samples that are BNI Syariah, BRI Syariah, BSM, BCA Syariah, and Bank Bukopin Syariah.

The research method used is a regression analysis of data panels. This research model can be implemented in the estimation of the equation as follows:

$$
\mathrm{NPF}=\mathrm{C}(1)+\mathrm{C}(2) * \mathrm{INFLASI}+\mathrm{C}(3) * \mathrm{GDP}+\mathrm{C}(4) * \mathrm{CAR}+\mathrm{C}(5) * \mathrm{FDR}
$$

\section{Hypothesis}

$\mathrm{H}_{1}$ : Alleged inflation, GDP, CAR, and FDR affect the NPF simultaneously.

$\mathrm{H}_{2}$ : Suspected inflation is positively influential against the NPF

$\mathrm{H}_{3}$ : Suspected GDP negatively affects NPF

$\mathrm{H}_{4}$ : CAR alleged negative impact on NPF

$\mathrm{H}_{5}$ : FDR suspected positive influence on NPF experience.

\section{Results and Discussion}

\section{Descriptive Statistics}

The results of the table 1 show that the amount of data used in this study was 100 observational data. The results also show that the average of each variable is higher than the standard deviation value. This means that the variable's tendency is on average because the average value is greater than the standard value of its deviation. 
Risks Of Sharia Commercial Bank In ...

Tabel 1. Descriptive Statistics

\begin{tabular}{cccccc}
\hline & $\mathbf{N}$ & Minimum & Maximum & Mean & Std. Deviation \\
\hline NPF & 100 & .01 & 7.85 & 3.3704 & 2.00195 \\
Inflation & 100 & 3.02 & 8.60 & 5.4185 & 1.77586 \\
GDP & 100 & 4.74 & 6.03 & 5.1535 & .34579 \\
CAR & 100 & 10.74 & 39.16 & 18.2477 & 7.06079 \\
FDR & 100 & 71.87 & 105.61 & 89.4323 & 7.30456 \\
Valid N (listwise) & 100 & & & & \\
\hline
\end{tabular}

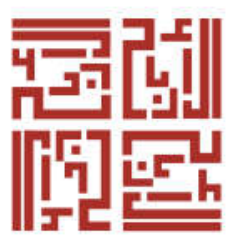

AL-ARBAH | 87

\section{Classic Assumption Test}

\section{Normality test}

The normality test results can be seen through the following table 2 . The significance value of Kolmogrov-Smirnov is greater than 0.05 i.e. acquired Kolmogrov value-Smirnov Z $=0.826$ with Asymp Sig $=0.503$. With Asymp Sig $=0.503>0.05$, so Kolmogrov-Smirnov test proves that the residual is a normal distribution.

\section{Multicollinearity Test}

Tabel 2. Normality Test One-Sample Kolmogorov-Smirnov Test

\begin{tabular}{ccc}
\hline & & $\begin{array}{c}\text { Unstandardized } \\
\text { Residual }\end{array}$ \\
\hline \multirow{2}{*}{ Normal Parametersa } & Mean & 100 \\
& Std. Deviation & .0000000 \\
Most Extreme Differences & Absolute & 1.25720687 \\
& Positive & .083 \\
& Negative & .083 \\
Kolmogorov-Smirnov Z & -.049 \\
Asymp. Sig. (2-tailed) & .826 \\
\hline
\end{tabular}

AL-ARBAH: Journal of Islamic Finance and Banking - Vol. 1 No. 1 (2019) 
Erlinda Kurnia Aufa, Cita Sary Dja'akum

Table 3. Multicollinearity Test Results Coefficients ${ }^{\mathrm{a}}$

\begin{tabular}{cccccccc}
\hline \multicolumn{9}{c}{$\begin{array}{c}\text { Unstandardized } \\
\text { Coefficients }\end{array}$} & \multicolumn{3}{c}{ Collinearity Statistics } \\
& Model & B & Std. Error & T & Sig. & Tolerance & VIF \\
\hline $\mathbf{1}$ & (Constant) & 18.031 & 2.438 & 7.395 & .000 & & \\
& INFLASI & -.106 & .090 & -1.179 & .241 & .656 & 1.523 \\
& GDP & -.846 & .382 & -2.211 & .029 & .951 & 1.051 \\
& CAR & -.199 & .019 & -10.387 & .000 & .907 & 1.102 \\
& FDR & -.068 & .021 & -3.231 & .002 & .701 & 1.426 \\
\hline
\end{tabular}

VIF value obtained from each independent variable is less than 10 and the tolerance value obtained shows some more than 0.10 , so it can be said that there is no multicollinearity. Thus, it can be concluded that based on tolerance and VIF values, this regression model is a reliable test to use. The multicollinearity test results can be seen through the following table 3 .

\section{Heteroscedasticity}

The Glejser test result above shows that none of the statistically significant independent variables affect the absolute value-dependent variable (AbsRES), seen from the value of its significance probability above $0.05(5 \%)$.

Table 4. Heteroscedasticity Test

\begin{tabular}{|c|c|c|c|c|c|c|}
\hline & \multirow[b]{2}{*}{ Model } & \multicolumn{2}{|c|}{$\begin{array}{l}\text { Unstandardized } \\
\text { Coefficients }\end{array}$} & \multirow{2}{*}{$\begin{array}{c}\text { Standardized } \\
\text { Coefficients } \\
\text { Beta }\end{array}$} & \multirow[b]{2}{*}{$T$} & \multirow[b]{2}{*}{ Sig. } \\
\hline & & B & Std. Error & & & \\
\hline \multirow[t]{5}{*}{1} & (Constant) & 3.828 & 1.363 & & 2.808 & .006 \\
\hline & INFLASI & .049 & .050 & .120 & .970 & .334 \\
\hline & GDP & -.420 & .214 & -.201 & -1.962 & .053 \\
\hline & CAR & .005 & .011 & .049 & .469 & .640 \\
\hline & FDR & -.011 & .012 & -.113 & -.945 & .347 \\
\hline
\end{tabular}


Risks Of Sharia Commercial Bank In ...

\section{Discussion}

According to the table 5 shows that simultaneous inflation, GDP, CAR, and FDR affect the FDR. Partially, inflation has a positive effect insignificant to the NPF. GDP has a significant negative impact on NPF. CAR's negative effect is not significant against the NPF. The FDR has a significant negative effect on the NPF. The value of the coefficient of determination using Adjusted R Square is 0.806258 or $80.6 \%$. This means that as much as $80.6 \%$ of the NPF variables can be explained by the inflation, GDP, CAR, and FDR variables in this study.

Taking into account the results of the table 5, are as follows:

Table 5. Hypothesis Test

\begin{tabular}{|c|c|c|c|c|}
\hline Variable & Coefficient & Std. Error & t-Statistic & Prob. \\
\hline C & 12.30574 & 1.852826 & 6.641606 & 0.0000 \\
\hline INFLASI? & 0.029913 & 0.068816 & 0.434675 & 0.6648 \\
\hline GDP? & -0.855664 & 0.262748 & -3.256589 & 0.0016 \\
\hline CAR? & -0.009222 & 0.031585 & -0.291974 & 0.7710 \\
\hline FDR? & -0.050535 & 0.016005 & -3.157455 & 0.0022 \\
\hline \multicolumn{5}{|l|}{ Fixed Effects (Cross) } \\
\hline BNIS-C & -0.889289 & & & \\
\hline BRIS-C & 1.151787 & & & \\
\hline _BSM-C & 1.673907 & & & \\
\hline -BCAS-C & -2.741970 & & & \\
\hline _BUKOPINS-C & 0.805565 & & & \\
\hline \multicolumn{5}{|c|}{ Cross-section fixed (dummy variables) } \\
\hline R-squared & 0.821914 & \multicolumn{2}{|c|}{ Mean dependent var } & 3.370400 \\
\hline Adjusted R-squared & 0.806258 & \multicolumn{2}{|c|}{ S.D. dependent var } & 2.001947 \\
\hline S.E. of regression & 0.881181 & \multicolumn{2}{|c|}{ Akaike info criterion } & 2.670581 \\
\hline Sum squared resid & 70.65960 & \multicolumn{2}{|c|}{ Schwarz criterion } & 2.905046 \\
\hline Log likelihood & -124.5290 & \multicolumn{2}{|c|}{ Hannan-Quinn criter. } & 2.765473 \\
\hline F-statistic & 52.49848 & \multicolumn{2}{|c|}{ Durbin-Watson stat } & 1.333522 \\
\hline Prob(F-statistic) & 0.000000 & & & \\
\hline
\end{tabular}

AL-ARBAH: Journal of Islamic Finance and Banking - Vol. 1 No. 1 (2019) 
1) The value of constants or fixed value in the equation above is 12.30574 . This number shows the magnitude of the NPF value. So that if the inflation, GDP, CAR, and FDR values are considered constant or 0 , the NPF growth value is $12.30574 \%$; 2) The inflation regression coefficient is 0.029913 which means that any increase in inflation by $1 \%$ increases the NPF by $0.029913 \%$ assuming another variable is considered fixed. Thus, the higher the value of Indonesian inflation, the higher the NPF value in the Sharia Bank; 3) The value of the GDP regression coefficient is- 0.855664 which means that every $1 \%$ GDP rise will decrease the NPF by $0.855664 \%$ assuming other variables are considered fixed. Thus, the higher the GDP value of Indonesia, the lower the NPF value in the Sharia Bank; 4) The value of the CAR regression coefficient of- 0.009222 which means any CAR increase of $1 \%$ will lower the NPF by $0.009222 \%$ assuming other variables are considered fixed. Thus, the higher the value of Sharia general Bank CAR, the lower the NPF value in the Sharia Bank; 5) The value of the FDR regression coefficient is 0.050535 which means that every increase in FDR $1 \%$ will lower the NPF by $0.050535 \%$ assuming another variable is considered fixed. Thus, the higher the value of the FDR Syariah General Bank, the lower the NPF value in Sharia Bank.

The results of the first hypothesis test showed that inflation had a positive direction but did not have a significant influence on the NPF Syariah General Bank. The results of this study were supported by research Masthuroh, et al. (2015) stating that when the inflation rate is rising, the NPF level will be increased, conversely. These two variables are directly proportional so they are said to have positive relationships. However, in this research, the results show that inflation is not significant in affecting NPF levels. This is because sharia banks have stronger durability than conventional banks. Sharia Bank has a product scheme that refers to 2 categories of economic activities such as production (profit sharing) and distribution (trading and tenancy). Therefore, sharia bank activities are categorized as investment banking and merchant/commercial banking.Besides, in carrying out its operations to replace the interest system with the share system. Thus, the impact of inflation can be reduced. The results of this study have the same results as 
some research. Research conducted by Ihsan and Mulyo Haryanto (2011) and Puspitasari (2012). They mentioned that inflation has no significant influence on the level of problematic financing (Mashturoh, et al., 2015).

The second hypothesis of the test showed that GDP had a negative direction but did not have a significant influence on the NPF Syariah General Bank. The results of this research are in line with the research conducted by Firmansyah (2014). GDP which is the indicator of the economy of society. Therefore, with increasing GDP, it is increasingly capable for the public to pay off its obligations, and vice versa. Thus, GDP hurts problematic financing.

The third hypothesis testing results show that CAR has a negative direction and has a significant effect on the NPF of Islamic Banks. The greater the CAR, the higher the ability of bank capital to maintain the possibility of risk of loss of business activities. Thus, the greater the CAR will reduce the level of problem financing.

The fourth hypothesis test results show that the FDR has a negative direction and has a significant influence on the NPF Syariah General Bank. The results of this study were supported by the research of Poetry and D Sanrego (2011) stating that when the LDR variable (loan to deposit ratio) conventional banks have increased, the NPL of conventional banks has decreased. Likewise with Sharia bank NPF, when sharia bank variable FDR has increased, NPF Sharia bank also decreased. This is in accordance with what was declared Sipahutar (2007) that with good quality LDR, credit expansion can make a good contribution to the increase in the banking profit, so the NPL will also decline (Poetry and D Sanrego, 2011).

\section{Conclusion}

Based on the results of data analysis and discussion on the influence of inflation, GDP, CAR, and FDR on the NPF, In partial, the test result of a regression data panel based on the results of the T-test indicates that: 1) The inflation variable has an insignificant positive influence on the NPF Syariah General Bank in the Indonesia period 2013-2017. This is evidenced by the value of the T-Statistic of 0.434675 with a significance of $0.6648>0.05 ; 2$ ) 
Erlinda Kurnia Aufa, Cita Sary Dja'akum

The GDP variable has a significant negative influence on the NPF Syariah General Bank in the Indonesia period 2013-2017. This is evidenced by the value of the T-Statistic of-3.256589 with a significance of $0.0016<0.05$; 3)CAR variables have an insignificant negative influence on the NPF Syariah General Bank in the Indonesia period 2013-2017. This is evidenced by the value of the T-Statistic of- 0.291974 with the significance of $0.7710>0.05$; The FDR variable has a significant negative influence on the NPF Syariah General Bank in the Indonesia period 2013-2017. This is evidenced by the value of the T-Statistic of-3.157455 with a significance of $0.0022<0.05$.

Simultaneously, the test result of a regression data panel based on the results of test $F$ showed that the variable inflation, GDP, CAR, and FDR jointly significantly affect the NPF Syariah general Bank in Indonesia period 20132017. This means that all of these variables are simultaneously instrumental in the efforts of NPF at Sharia Bank in Indonesia period 2013-2017.

\section{References}

Amin, Rukhul, Haqiqi Rafsanjani and Abdul Mujib. (2017). "Factors affecting Non-Performing Financing: Case studies on Sharia banks and BPR in Indonesia", Masharif al-Syariah journal: Sharia Economics and Banking Journal, Vol. 2, No. 2:2.

Asnaini, Sri Wahyuni. (2014). "Factors affecting Non-Performing Financing (NPF) on sharia Bank in Indonesia", Diligent Journal, Vol. 5, No. 02:265.

Auliani, Mia Maraya and Syaichu. (2016). "Analysis of the influence of Internal factors and external factors to the level of problem financing in Sharia banks in Indonesia period year 2010-2014", Diponegoro Journal of Management, Vol. 05, No. 03:1.

Mutamimah and Siti Nur ZaidahChasanah. (2012). "External and Internal analysis in determining Non-Performing Financing of Sharia public Bank in Indonesia", Business and Economic Journal, Vol. 19, No. 01:54.

Muhammad. (2014). "Causal factors for problematic financing in Indonesian Sharia financing Bank", Economics and Business Journal, Vol. 08, No. 02:83. 
Risks Of Sharia Commercial Bank In ...

Heffernan, Shelagh. (2005). Modern Banking. Chichester: John Wiley \& Sons.

Association of Indonesian bankers. (2015). Managing the Sharia Bank financing business Syariah Financing Certification module I, Jakarta: PT GramediaPustaka Utama.

Machmud, Amir and Rukmana. Bank Syariah, Jakarta: Erlangga, 2010.

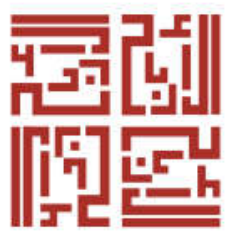

Mashturoh, Aidah, Efriyanto and Herbirowo Nugroho. (2015) "The influence of Gross Domestic Product and inflation on Non-Performing Financing in PT Bank Muamalat Indonesia period 2006-2013", Journal of Accounting, Finance and Banking, Vol. 01, No. 04:316.

Misman, FaridahNajuna, Ishaq Bhatti, Weifang Lou, SyamsyulSamsudin and Nor Hadaliza Abd Rahman. (2015). "Islamic Banks Credit Risk: A Panel Study". Procedia Economics and Finance 31, 75 - 82.

Poetry, ZakiyahDwi and Yulizar D Sanrego. (2011). "Macro and Micro variable influence on NPL conventional banking and Sharia banking NPF", Tazkia, Vol. 06, No. 02:95.

Popita, the Holy Mares of Ana. (2013). "Analysis of the cause of NonPerforming Financing of Sharia Bank in Indonesia", Journal of Accountancy, Vol. 02, No. 04:405.

Purnamasari, Amalia Eka and Musdholifah. (2016). " Analysis of external and Internal Bank factors against the risk of financing Sharia Bank in Indonesia period 2012-2015 ", business and Management, Vol. 9, No. $1: 14$

Setiawan, Chandra and Monita Eggy Putri. (2013). "Non-Performing Financing and Bank Efficiency of Islamic Banks in Indonesia". Journal of Islamic Finance and Business Research. Volume 2 number 1, 58-76.

Shingjergi, Ali. and Iva Shingjergi. (2013). "An Analysis of the Nonperforming Loans in the Albanian Banking System". International Journal of Business and Commerce.Volume 2. No. 6, 01-11.

Wibowo, Dedi and Haifa. (2015) "The Influence of Internal and Macroeconomic Factors on Non-Performing Financing of Sharia Banking in Indonesia: 2010 Period: 01-2014: 04", Nisbah Journal, Vol. 01, No. 02: 76. 
Erlinda Kurnia Aufa, Cita Sary Dja'akum

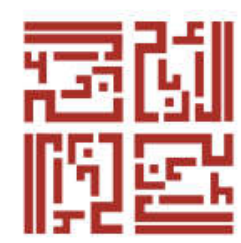

AL-ARBAH | 94 